\title{
A PCR-Based Method for the Rapid Detection of Chondrostereum purpureum in Apple
}

\author{
D. Grinbergs, ${ }^{1,2}$ J. Chilian, ${ }^{1, \dagger}$ J. Carrasco-Fernández, ${ }^{1}$ A. France, ${ }^{1}$ E. Moya-Elizondo, ${ }^{2}$ and M. Gerding ${ }^{2}$ \\ ${ }^{1}$ Instituto de Investigaciones Agropecuarias, INIA, Av. Vicente Méndez 515, Chillán, Chile \\ ${ }^{2}$ Universidad de Concepción, Av. Vicente Méndez 595, Chillán, Chile
}

\begin{abstract}
Silverleaf caused by the basidiomycete Chondrostereum purpureum affects numerous woody species, including fruit tree crops like apple, resulting in wood necrosis and foliar silvering. There are no curative alternatives for this disease, and its management is by prevention methods. Therefore, the aim of this study was to develop a rapid diagnostic tool for the detection and identification of $C$. purpureum directly from woody tissues to help distinguish the pathogen from other basidiomycetes that are commonly found on apple. The silverleaf pathogen was isolated from different hosts and locations, and Koch's postulates were performed by inoculating the isolates on apple cuttings and measuring internal necrosis. A previously described APN 1 pair of primers specificity was also tested against 25 C. purpureum isolates in this study,

of incubation. To prove the efficiency of the method in the field, DNA from healthy nursery plants inoculated with two virulent isolates, and naturally infected plants showing different levels of foliar symptoms, were tested. Presence of the fungus was verified by reisolation on APDA in all assays. Koch's postulates indicated that all C. purpureum isolates were pathogenic, showing different virulence levels, and APN 1 primers were able to discriminate them from other basidiomycetes. The method was also able to detect $C$. purpureum from artificially inoculated plants as well as naturally infected ones, demonstrating that the protocol may become a rapid minimally destructive diagnostic tool to detect the pathogen without the need to isolate it from tissues, and thus taking measures to prevent its dissemination.
\end{abstract} using other wood rotting species as negative controls. Seven virulent isolates were inoculated on apple cuttings, and DNA was extracted from the cuttings' sawdust and amplified using APN 1, after 22 days
Keywords: pathogen detection, silverleaf, wood diseases, fungal canker, molecular detection, Chondrostereum purpureum, Malus domestica
Chondrostereum purpureum (Pers. Ex Fr.) Pouzar is an important wound pathogen that causes silverleaf disease in more than 230 woody species, including major fruit crops such as peach, plum, cherry, blueberry, apple, and also ornamental and forest crops (Bus et al. 1996; Ogawa et al. 2000; Setliff 2002; Spiers and Brewster 1997; Spiers and Hopcroft 1988). This basidiomycete fungus disseminates through airborne spores from different inoculum sources such as infected fruit orchards, windblown trees, logged areas, woodpiles, and pruned branches (De Jong et al. 1990; Vartiamäki et al. 2009), reaches wounded wood, like grafts and pruning cuts, and causes infection. Basidiospores germinate and mate with compatible hyphae forming heterokaryotic mycelia that grow deeper into the wood, producing the enzyme that causes the disease foliar symptoms. Subsequently, the fungus occludes the xylem, kills the plant, and develops resupinated carpophores that release spores under optimal meteorological conditions (Pearce et al. 1994; Simpson et al. 2001; Spiers et al. 1987).

Silverleaf disease is considered a major economic disease for several fruit crops in Chile, with new host species and cultivars for $C$. purpureum reported yearly (France et al. 2017; Grinbergs et al. 2019). Apple is one of the most susceptible species, and silverleaf occurs throughout all the apple producing area, having a negative impact on the productivity and longevity of apple orchards and nurseries (Spiers and Brewster 1997; Spiers et al. 1998). During the past several years, disease incidence and severity have

${ }^{\dagger}$ Corresponding author: J. Chilian; jchilian@inia.cl

Funding: This research was supported by funding from FONDEF (project ID16I10272) and from CONICYT Ph.D. scholarship DOCNAC 21172006.

The author(s) declare no conflict of interest.

Accepted for publication 10 October 2019.

(C) 2020 The American Phytopathological Society increased due to changes in management practices, such as severe pruning. On the other hand, there are not any effective curative treatments against silverleaf. Thus, the disease control relies on preventive management, such as the use of pruning paints amended with fungicides, reduction of inoculum sources (Bus et al. 1996; Spiers and Brewster 1997), avoidance of nursery plants infection, and early detection of the disease, especially in nursery mother plants, to prevent infection of newly grafted plants. However, early detection is not an easy task due to the lack of foliar symptoms at early stages of infection and considering that necrotic symptoms are visible only when infected wood is cut.

Diagnosis of wood pathogens has been traditionally performed by isolation in culture media (Lecomte and Bailey 2011; Luque et al. 2014; Rolshausen et al. 2010; Sosnowski et al. 2008; Úrbez-Torres et al. 2009). Results through this method can take days or even weeks (Capote et al. 2012), and may lead to false negative results, due to the overgrowth and/or contamination of other fungi in the petri plates, which can hide the primary pathogen. On the other hand, once the isolates are obtained, the accurate identification of species can be difficult due to the lack of morphological characters (Pavlic et al. 2009; Phillips et al. 2012; Rolshausen et al. 2004). This difficulty is amplified when someone tries to identify $C$. purpureum, since most isolates of this fungus are not able to develop reproductive structures in vitro, which are necessary for taxonomic identification. To reduce this laborious and time-consuming task, and to increase the accuracy and reliability of the diagnosis, several molecular techniques have been developed, with polymerase chain reaction (PCR) being the most popular (Capote et al. 2012).

Numerous culture-dependent and independent molecular methods have been developed to detect wood pathogens in plants (Alves et al. 2007; Catal et al. 2007; Morales-Cruz et al. 2017; Pouzoulet et al. 2017; Rolshausen et al. 2004; Spagnolo et al. 2011; ÚrbezTorres et al. 2013). Accordingly, Becker et al. (1999) described a method for identifying $C$. purpureum from pure cultures using specific primers in PCR. Therefore, the aim of this study was to develop and standardize a rapid diagnostic tool for the detection 
and identification of $C$. purpureum directly from woody tissues to be used as a minimally destructive standard method that can reliably discriminate from other apple wood inhabiting basidiomycetes.

\section{Materials and Methods}

Fungal isolates. $C$. purpureum was isolated from different infected hosts showing foliar silvering and wood necrotic symptoms, at different geographic locations in Chile, during 2010 to 2018. For isolation, branches showing silver leaves were cut from the trees and brought to the laboratory. Subsequently, the bark of the branches was removed and wooden discs were cut, superficially disinfected for 3 min using 3\% sodium hypochlorite and 70\% ethanol, rinsed with sterile distilled water, and flamed. The sterilized discs then were plated in petri plates containing acidified quarter-strength potato dextrose agar (APDA) (25\% PDA acidified with $0.1 \mathrm{vol} / \mathrm{vol} 85 \%$ lactic acid Winkler) and water agar (WA), and incubated at $25^{\circ} \mathrm{C}$ in darkness until mycelial development. Fungal tips were transferred from the growing colonies to PDA plates to obtain pure cultures. The isolates were identified by their cultural characteristics on PDA, morphometry of the mycelium, and spores from pseudo-basidiocarps developed in culture media, and by the sequence analysis of the ITS regions subjected to NCBI BLAST search.

Extraction of genomic DNA. Mycelium $(0.1 \mathrm{~g})$ was collected from the edge of pure cultures of the different isolates growing on PDA and transferred to microtubes containing $500 \mu l$ of the extraction buffer ( $2 \%$ hexadecyltrimethylammonium bromide [CTAB], $2 \%$ polyvinylpyrrolidone [PVP], $100 \mathrm{mM}$ Tris HCL [pH 8.0], $25 \mathrm{mM}$ EDTA, $1.5 \mathrm{M} \mathrm{NaCl}$ ) and $0.2 \% \beta$-mercaptoethanol, added just before use, and homogenized using plastic pestles. Tubes were incubated for $30 \mathrm{~min}$ at $65^{\circ} \mathrm{C}$ and cooled at room temperature (RT). Subsequently, the content was mixed with equal volume of chloroform: isoamyl alcohol (24:1) and centrifuged at 10,000 rpm for $10 \mathrm{~min}$ at RT. The supernatant was recovered and mixed with two volumes of isopropanol and stored overnight at $4{ }^{\circ} \mathrm{C}$. The mixture was then centrifuged at $10,000 \mathrm{rpm}$, at $4^{\circ} \mathrm{C}$ for $10 \mathrm{~min}$. Isopropanol was removed and the pellet washed with ethanol $(70 \%)$ by centrifuging as in the previous stage. The DNA was resuspended into Tris $10 \mathrm{mM}$ EDTA $1 \mathrm{mM}$ (TE 10:1) buffer $(100 \mu \mathrm{l})$, quantified using an Epoch 2 Microplate Spectrophotometer (BioTek Instruments Inc., Winooski, VT, U.S.A.), adjusting to a final concentration of $20 \mathrm{ng} / \mu \mathrm{l}$, and stored at $-20^{\circ} \mathrm{C}$ until use.

PCR amplification. PCR was performed in a $50 \mu \mathrm{l}$ reaction mixture containing $1 \times$ PCR buffer $\left(4.0 \mathrm{mM} \mathrm{MgCl}_{2}, 0.2 \mathrm{mM}\right.$ each $\mathrm{dNTP}$, $0.2 \mathrm{mM}$ of each primer, $25 \mathrm{U}$ of GoTaq G2 Flexi DNA Polymerase (Promega, Madison, WI, U.S.A.), and $20 \mathrm{ng} / \mu \mathrm{l}$ of DNA template) by using a 2720 Thermal Cycler (Applied Biosystems Inc., Foster City, CA, U.S.A.). Genomic DNA of the isolates were amplified using ITS1 and ITS4 primers (White et al. 1990), using 30 cycles of denaturation at $94^{\circ} \mathrm{C}$ for $1 \mathrm{~min}$, annealing at $52^{\circ} \mathrm{C}$ for $1.5 \mathrm{~min}$, and extension at $72^{\circ} \mathrm{C}$ for $2 \mathrm{~min}$. PCR products were checked with electrophoresis (1.5\% agarose) and then sequenced by Macrogen Inc. (Seoul, Korea). Sequence chromatograms were assembled and manually edited using Sequencher 5.4.6 software (Gene Codes Corporation, Ann Arbor, MI, U.S.A.) and the new consensus sequences compared (NCBI BLAST) to those previously published in GenBank.

Pathogenicity tests. Koch's postulates were performed for all 25 C. purpureum isolates obtained from different fruit tree species (Table 1). Twigs from healthy apple plants var. Royal Gala, 1.5 to $2 \mathrm{~cm}$ in diameter, were collected in winter, when natural infection occurs, superficially disinfected, and aseptically cut to obtain $20-\mathrm{cm}-$ long cuttings. Mycelial plugs $1 \mathrm{~cm}$ in diameter were collected from actively growing colonies on PDA, placed on the apical edge of the cuttings, and the inoculation point sealed using plastic film. Ten replicates were inoculated for each isolate, and 10 cuttings were used as controls, and inoculated with sterile 1-cm agar plugs.

Table 1. Isolate, plant host, source, geographic origin, and GenBank accession number of 30 wood fungi isolates used in this study

\begin{tabular}{|c|c|c|c|c|c|}
\hline Isolate $^{\mathbf{a}}$ & Species & Host & \multicolumn{2}{|c|}{ Geographic origin } & $\begin{array}{c}\text { ITS GenBank accession } \\
\text { number }^{\mathbf{b}}\end{array}$ \\
\hline RGM 2167 & Chondrostereum purpureum & Actinidia deliciosa & Temuco & $38^{\circ} 41^{\prime} 41^{\prime \prime} \mathrm{S} 72^{\circ} 25^{\prime} 01^{\prime \prime} \mathrm{W}$ & MK788300 \\
\hline RGM 146 & Chondrostereum purpureum & Malus domestica & Los Angeles & $37^{\circ} 14^{\prime} 12^{\prime \prime} \mathrm{S} 72^{\circ} 14^{\prime} 32^{\prime \prime} \mathrm{W}$ & MK322264 \\
\hline RGM 191 & Chondrostereum purpureum & Malus domestica & Longaví & $35^{\circ} 56^{\prime} 57^{\prime \prime} \mathrm{S} 71^{\circ} 40^{\prime} 59^{\prime \prime} \mathrm{W}$ & MK322282.1 \\
\hline RGM 206 & Chondrostereum purpureum & Malus domestica & Villa Alegre & $35^{\circ} 41^{\prime} 45^{\prime \prime} \mathrm{S} 71^{\circ} 40^{\prime} 54^{\prime \prime} \mathrm{W}$ & MK322288.1 \\
\hline RGM 1323 & Chondrostereum purpureum & Malus domestica & Graneros & $34^{\circ} 03^{\prime} 46^{\prime \prime} \mathrm{S} 70^{\circ} 42^{\prime} 40^{\prime \prime} \mathrm{W}$ & MK322312 \\
\hline RGM 2161 & Chondrostereum purpureum & Malus domestica & Pelequén & $34^{\circ} 26^{\prime} 28^{\prime \prime} \mathrm{S} 70^{\circ} 54^{\prime} 09^{\prime \prime} \mathrm{W}$ & MH270441 \\
\hline RGM 2168 & Chondrostereum purpureum & Malus domestica & Rengo & $34^{\circ} 24^{\prime} 02^{\prime \prime} \mathrm{S} 70^{\circ} 50^{\prime} 11^{\prime \prime} \mathrm{W}$ & MH270447 \\
\hline RGM 2169 & Chondrostereum purpureum & Malus domestica & San Fernando & $34^{\circ} 09^{\prime} 32^{\prime \prime} \mathrm{S} 70^{\circ} 47^{\prime} 44^{\prime \prime} \mathrm{W}$ & MH270448 \\
\hline RGM 213 & Chondrostereum purpureum & Prunus avium & Vilcún & $38^{\circ} 44^{\prime} 31^{\prime \prime} \mathrm{S} 72^{\circ} 21^{\prime} 36^{\prime \prime} \mathrm{W}$ & MK322292.1 \\
\hline RGM 267 & Chondrostereum purpureum & Prunus persica & La Cruz & $32^{\circ} 49^{\prime} 15^{\prime \prime} \mathrm{S} 70^{\circ} 47^{\prime} 44^{\prime \prime} \mathrm{W}$ & MK322304.1 \\
\hline RGM 2160 & Chondrostereum purpureum & Prunus persica & Pelequén & $34^{\circ} 26^{\prime} 28^{\prime \prime} \mathrm{S} 70^{\circ} 54^{\prime} 09^{\prime \prime} \mathrm{W}$ & MK788299.1 \\
\hline RGM 2164 & Chondrostereum purpureum & Psoralea glandulosa & Cato & $36^{\circ} 31^{\prime} 23^{\prime \prime} \mathrm{S} 71^{\circ} 46^{\prime} 04^{\prime \prime} \mathrm{W}$ & MH270443.1 \\
\hline RGM 2159 & Chondrostereum purpureum & Pyrus pyrifolia & Chillán Viejo & $36^{\circ} 38^{\prime} 25^{\prime \prime} \mathrm{S} 72^{\circ} 09^{\prime} 09^{\prime \prime} \mathrm{W}$ & MH270440.1 \\
\hline RGM 3869 & Chondrostereum purpureum & Quercus ilex & Cato & $36^{\circ} 31^{\prime} 23^{\prime \prime} \mathrm{S} 71^{\circ} 46^{\prime} 04^{\prime \prime} \mathrm{W}$ & MK788297.1 \\
\hline RGM 2166 & Chondrostereum purpureum & Salix babilonica & Cato & $36^{\circ} 31^{\prime} 23^{\prime \prime} \mathrm{S} 71^{\circ} 46^{\prime} 04^{\prime \prime} \mathrm{W}$ & MH270445.1 \\
\hline RGM 122 & Chondrostereum purpureum & Vaccinium corymbosum & Traiguén & $38^{\circ} 16^{\prime} 42^{\prime \prime} \mathrm{S} 72^{\circ} 39^{\prime} 41^{\prime \prime} \mathrm{W}$ & MK322253.1 \\
\hline RGM 148 & Chondrostereum purpureum & Vaccinium corymbosum & La Unión & $40^{\circ} 16^{\prime} 50^{\prime \prime} \mathrm{S} 73^{\circ} 03^{\prime} 41^{\prime \prime} \mathrm{W}$ & MK262906.1 \\
\hline RGM 156 & Chondrostereum purpureum & Vaccinium corymbosum & San Carlos & $36^{\circ} 25^{\prime} 24^{\prime \prime} \mathrm{S} 71^{\circ} 55^{\prime} 29^{\prime \prime} \mathrm{W}$ & MK322269.1 \\
\hline RGM 247 & Chondrostereum purpureum & Vaccinium corymbosum & Quiriquina & $36^{\circ} 50^{\prime} 53^{\prime \prime} \mathrm{S} 72^{\circ} 06^{\prime} 07^{\prime \prime} \mathrm{W}$ & MK322296.1 \\
\hline RGM 249 & Chondrostereum purpureum & Vaccinium corymbosum & Fresia & $41^{\circ} 08^{\prime} 44^{\prime \prime} \mathrm{S} 73^{\circ} 26^{\prime} 23^{\prime \prime} \mathrm{W}$ & MK322298.1 \\
\hline RGM 251 & Chondrostereum purpureum & Vaccinium corymbosum & Gorbea & $39^{\circ} 05^{\prime} 48^{\prime \prime} \mathrm{S} 72^{\circ} 39^{\prime} 27^{\prime \prime} \mathrm{W}$ & MK322299.1 \\
\hline RGM 225 & Chondrostereum purpureum & Vaccinium corymbosum & Vilcún & $38^{\circ} 44^{\prime} 31^{\prime \prime} \mathrm{S} 72^{\circ} 21^{\prime} 36^{\prime \prime} \mathrm{W}$ & MK322293.1 \\
\hline RGM 265 & Chondrostereum purpureum & Vaccinium corymbosum & Quiriquina & $36^{\circ} 50^{\prime} 53^{\prime \prime} \mathrm{S} 72^{\circ} 06^{\prime} 07^{\prime \prime} \mathrm{W}$ & MK322302 \\
\hline RGM 2163 & Chondrostereum purpureum & Vaccinium corymbosum & Talca & $35^{\circ} 23^{\prime} 54^{\prime \prime} \mathrm{S} 71^{\circ} 35^{\prime} 43^{\prime \prime} \mathrm{W}$ & MH270442.1 \\
\hline RGM 2165 & Chondrostereum purpureum & Vaccinium corymbosum & Cato & $36^{\circ} 31^{\prime} 25^{\prime \prime} \mathrm{S} 71^{\circ} 46^{\prime} 34^{\prime \prime} \mathrm{W}$ & MH270444.1 \\
\hline RGM 181 & Bjerkandera adusta & Malus domestica & Renaico & $37^{\circ} 39^{\prime} 30^{\prime \prime} \mathrm{S} 72^{\circ} 34^{\prime} 28^{\prime \prime} \mathrm{W}$ & MK322277.1 \\
\hline RGM 1317 & Ganoderma applanatum & Vaccinium corymbosum & Los Angeles & $37^{\circ} 14^{\prime} 12^{\prime \prime} \mathrm{S} 72^{\circ} 14^{\prime} 32^{\prime \prime} \mathrm{W}$ & MK788298.1 \\
\hline RGM 2171 & Schizophyllum commune & Malus domestica & Chillán & $36^{\circ} 35^{\prime} 40^{\prime \prime} \mathrm{S} 72^{\circ} 05^{\prime} 15^{\prime \prime} \mathrm{W}$ & МH301328.1 \\
\hline RGM 1319 & Stereum sp. & Vaccinium corymbosum & Paillaco & $40^{\circ} 07^{\prime} 48^{\prime \prime} \mathrm{S} 72^{\circ} 39^{\prime} 27^{\prime \prime} \mathrm{W}$ & MK322311.1 \\
\hline RGM 187 & Trametes versicolor & Prunus avium & Collipulli & $37^{\circ} 57^{\prime} 57^{\prime \prime} \mathrm{S} 72^{\circ} 25^{\prime} 53^{\prime \prime} \mathrm{W}$ & MK322281.1 \\
\hline
\end{tabular}

\footnotetext{
${ }^{a}$ Isolates were identified, characterized, and stored in the Chilean Collection of Microbial Genetic Resources (CChRGM) www.cchrgm.cl, Chillán, Chile.
}

b ITS 4 and 5. ITS = internal transcribed spacer. 
Cuttings were vertically arranged in a plastic pot with $3 \mathrm{~cm}$ distilled sterile water on the bottom and incubated at $22^{\circ} \mathrm{C}$ for 21 days. After the incubation period, the cuttings were cut longitudinally to observe and measure the internal necrosis of the wood. The pathogen was reisolated by plating wood pieces from the margins of necrotic lesions on APDA and incubating at $25^{\circ} \mathrm{C}$, and the obtained isolates were compared with the ones used initially for the inoculations.

C. purpureum discrimination using specific primers. The ability of the primers to discriminate C. purpureum from other wood-rotting basidiomycetes was verified. DNA from pure cultures of the $C$. purpureum isolates was obtained using the previously described method. Additionally, five isolates of the basidiomycete fungi Bjerkandera adusta, Ganoderma applanatum, Schizophyllum commune, Stereum sp., and Trametes versicolor were obtained from the Chilean Microbial Genetic Resources Collection (CChRGM, Instituto de Investigaciones Agropecuarias, Chillán, Chile) (Table 1), plated on PDA, and their DNA isolated from the growing colonies.

Genomic DNA was amplified using APN 1 C. purpureum specific primers described by Becker et al. (1999) which amplify a 500-bp fragment located within the intergenic spacer (IGS) region of $C$. purpureum genomic rDNA. PCR was performed using 30 cycles of denaturation at $94^{\circ} \mathrm{C}$ for $1 \mathrm{~min}$, followed by annealing at $60^{\circ} \mathrm{C}$ for $1 \mathrm{~min}$, and extension at $72^{\circ} \mathrm{C}$ for $2 \mathrm{~min}$. The PCR products $(20 \mu \mathrm{l})$ were analyzed on $1.5 \%$ agarose gels, using a $1-\mathrm{kb}$ DNA ladder (Maestrogen Inc., Xiangshan Dist., Hsinchu, Taiwan) as molecular size standard. After electrophoresis for $2 \mathrm{~h}$ at $7.5 \mathrm{~V} / \mathrm{cm}$, gels were stained with ethidium bromide $\left(1 \mu \mathrm{g} / \mathrm{ml}^{-1}\right)$ and digitally recorded.

For isolates where bands were not visible, to discriminate between a failed PCR reaction and a null allele in the genomic DNA, extracted DNA was subjected to PCR amplification using ITS1 and ITS4 primers that are specific to fungi and to basidiomycetes, respectively.

Detection of $\boldsymbol{C}$. purpureum from cuttings. $C$. purpureum isolates RGM 146, RGM 191, RGM 206, RGM 1323, RGM 2161, RGM 2168, and RGM 2169 were inoculated on healthy apple cuttings of the var. Royal Gala. Inoculation and incubation methods were identical with the ones described for the pathogenicity tests. Seven replicates were inoculated for each isolate and 10 cuttings were used as controls and inoculated with a sterile agar plug. After the incubation period, samples of sawdust produced with a sterile $0.2 \times 4 \mathrm{~cm}$ wood drill were collected. The wood drill was superficially disinfected with ethanol between samples; the samples were taken $10 \mathrm{~cm}$ under the inoculation point and at $1 \mathrm{~cm}$ depth.

Sawdust was frozen and ground to a fine powder in liquid nitrogen. Subsequently, based on the protocols described by Jasalavich et al. (2000) and Guglielmo et al. (2010), $500 \mu \mathrm{l}$ of the extraction buffer was added to $100 \mathrm{mg}$ of sawdust, and the mixture incubated for $60 \mathrm{~min}$ at $65^{\circ} \mathrm{C}$. The following stages were identical to the DNA extraction protocol from pure cultures previously described.

In order to confirm the presence and viability of the pathogen in the cuttings, wooden discs were cut next to the sawdust sampling point. The bark of each disc was removed and the discs were

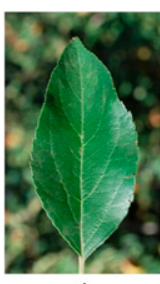

1
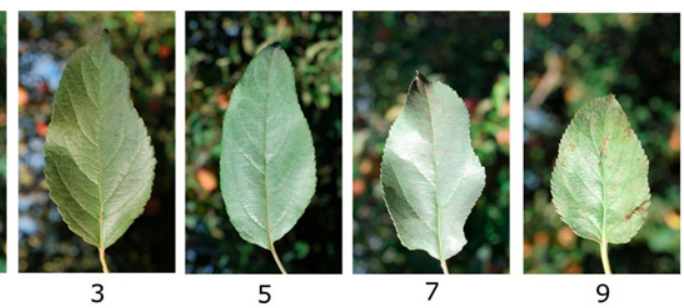

Fig. 1. Visual severity scale (1-9) for silverleaf disease foliar symptoms, where: $1=$ healthy or apparently healthy leaf, $3=$ epidermis is partially detached from the mesophyll and the color is lighter than in healthy leaves, $5=$ more than $75 \%$ of the leaf epidermis is detached from the mesophyll and the leaf is beginning to look silver, $7=100 \%$ of the epidermis is detached from the mesophyll and the leaf is completely silver and shiny, $9=$ epidermis is peeled off from the leaf and mesophyll begins to oxidize. $2,4,6$, and 8 grades indicate intermediate symptom severity between the previous and the following grade. superficially disinfected using the protocol described above, plated on PDA plates, and incubated at $25^{\circ} \mathrm{C}$ in darkness until mycelial development.

Detection of $C$. purpureum from inoculated plants. Healthy scions of the var. Gala Brookfield and var. Granny Smith were grafted on healthy rootstocks var. M Pajam 9, at the beginning of spring of 2016. Plants were inoculated in the graft point with 1.2$\mathrm{cm}$-diameter mycelial plugs from two actively growing isolates of C. purpureum (RGM 191 and RGM 2161) on PDA. Twenty-five plants from each variety were inoculated with each isolate, and 10 plants with a sterile agar plug were used as controls.

Inoculated plants were planted in a mixture of soil, peat, rice cape, and perlite $(2: 2: 1: 1)$ and incubated under shade house conditions $\left(\max 29.8^{\circ} \mathrm{C}\right.$, $\min 11.6^{\circ} \mathrm{C}$, average $20.1^{\circ} \mathrm{C}$ ) for 35 days. After the incubation period, sawdust samples were collected $5 \mathrm{~cm}$ above the graft and $1 \mathrm{~cm}$ deep, using the same drill and disinfection with ethanol between samples as described above. Genomic DNA extraction from the sawdust was identical to that described earlier for inoculated apple cuttings. The pathogen was reisolated from each plant by plating wood discs collected from the necrosis progress area by using the previously described protocol.

Detection of $C$. purpureum from naturally infected plants. The detection method of the pathogen was validated in nursery and orchard plants. For nursery validation, 20 symptomatic 2 -yearold nursery plants, ready for marketing (var. Brookfield grafted on dwarfing rootstock var. Pi 33), were randomly selected from a $2.500 \mathrm{~m}^{2}$ planted area and assessed for infection. Plants were labeled in summer, when foliar symptoms were visible (grade 5 to 9) according to a symptom severity scale described in Figure 1. Subsequently, in winter, when plants are regularly harvested, sample plants were collected as well, and carried to the laboratory. Three healthy nursery plants were used as negative controls. Sawdust samples were collected $10 \mathrm{~cm}$ above the graft, using the same drill technique for cuttings and inoculated plants. Perforations were sealed with a paste of acrylic-vinyl-natural fiber origin to avoid the entrance of pathogens.

DNA isolation and amplification were performed using the same procedures as for cuttings and inoculated plants. Wooden discs were excised and plated aseptically on APDA plates for reisolation of the pathogen and validation of PCR results.

To validate the method in adult plants, 14-year-old apple trees var. Gala Brookfield, from an orchard located near Chillán, in the central valley of Chile ( $\left.36^{\circ} 31^{\prime} 11^{\prime \prime} \mathrm{S} 71^{\circ} 50^{\prime} 19^{\prime \prime} \mathrm{W}\right)$, were assessed. Ten plants were selected from an $800 \mathrm{~m}^{2}$ surface, all of them showing different foliar symptoms intensity, grade 3 to 9 in the severity scale (Fig. 1), and five healthy nursery plants were considered as negative controls. Sawdust samples were collected from the main trunk, $30 \mathrm{~cm}$ above the soil and $3 \mathrm{~cm}$ depth, using a $0.5 \times 50 \mathrm{~mm}$ long disinfected drill, and immediately stored at $-20^{\circ} \mathrm{C}$ until use. The DNA extraction protocol and PCR conditions were as described earlier.

To confirm the presence of $C$. purpureum, wood plugs were collected from the trunk, next to the sawdust collection point, using a 15-mm-diameter increment borer. Plugs were aseptically cut into discs, superficially disinfected, plated on PDA, and incubated for fungal development, as previously described.

\section{Results}

C. purpureum was successfully isolated from necrotic woody tissues of silverleaf symptomatic plants of different hosts. Fungal isolates developed flat, coarsely floccose or cottony regular colonies on PDA, with pale colored aerial mycelia, white to light yellow, and with clamp connections. After 21 to 33 days of incubation at $25^{\circ} \mathrm{C}, 35 \%$ of the isolates developed beige or yellowish fruitbody crusts with apiculate basidiospores on the edge of the plates. Spores were hyaline, ovoid to subglobose, 6.2 (4.5-7.1) $\mu \mathrm{m} \times 3.3$ (2.5-4.1) $\mu \mathrm{m}$ in size $(n=35)$. Both macroscopic and microscopic morphometrical characteristics accorded to those described in literature for $C$. purpureum (Spiers et al. 2000). Additionally, the molecular sequence of $5.8 \mathrm{~S}$ gene confirmed $C$. purpureum as the fungal species. Sequences were deposited at the National Center for Biotechnology Information (NCBI) and at the European Nucleotide Archive (EMBL), 
and both confirmed the molecular identity of the 25 isolates as $C$. purpureum (Table 1).

Koch's postulates indicated that all the $C$. purpureum isolates were pathogenic, since the inoculated cuttings developed wood internal necrosis after the incubation period, extending from the point of inoculation to the opposite edge. However, isolates were diverse in their virulence, and the length of the necrotic discoloration varied from 3.1 to $14.0 \mathrm{~cm}$ (15.3-70.5\% of the cutting length) (Fig. 2A). When reisolated, the fungus was able to grow from the wooden discs plated on APDA, fulfilling Koch's postulates. The isolates' morphological characteristics agreed with the inoculated ones and with the features described in literature (Spiers et al. 2000). Control cuttings inoculated with sterile agar did not develop wood staining, and no fungus was able to grow from wooden discs on APDA.

Specificity of the primers to the pathogen was confirmed through PCR amplification using DNA extracted from the 25 isolates of $C$. purpureum and five other basidiomycete isolates, using APN 1 primers. All C. purpureum isolates, despite their host species origin, produced an intensely staining discrete band of $500 \mathrm{bp}$ corresponding to ribosomal DNA. On the other hand, genomic DNA from the other fungal species tested (Bjerkandera adusta, Ganoderma applanatum, Stereum sp., Trametes versicolor, and Schizophyllum commune) were not able to produce the band, as well as the controls (Fig. 2B). Meanwhile, template DNA of the non-C. purpureum reference isolates amplified using ITS primers, yielded an intensely staining $750 \mathrm{bp}$, indicating that they were basidiomycetes (Fig. 2C).

A procedure for genomic DNA extraction from apple woody tissues was evaluated and shown to be suitable to obtain an adequate quality and yield. Thus, it was possible to obtain high-quality DNA from the inoculated cuttings with the different $C$. purpureum isolates. Furthermore, although the DNA isolation method was designed for total DNA, from plants and fungi, the use of APN 1 specific primers in PCR allowed the amplification of the specific target sequence and the discrimination of $C$. purpureum positive cuttings from the controls inoculated with a sterile agar plug (Fig. 3A and C). In addition, all the inoculated $C$. purpureum isolates were successfully reisolated on PDA from the inoculated cuttings (Fig. 3B).

The inoculation method by the graft, using the virulent apple isolates RGM 191 and RGM 2161, successfully reproduced foliar symptoms in $100 \%$ of the var. Royal Gala plants. In var. Granny Smith, the RGM 191 inoculum was able to produce silverleaf disease in $100 \%$ of the nursery plants and the RGM 2161 in only $92 \%$. Necrotic symptoms were visible on the stained collected sawdust for DNA isolation and when plants were destroyed for subsequent isolation of the pathogen from symptomatic wood. The specific primers amplification allowed the identification of artificially inoculated and positively infected plants, compared with controls, indicating that it was possible to detect the fungus from living plants, using this method (Fig. 3D). Furthermore, it was possible to reisolate the fungus in $100 \%$ of the symptomatic plants inoculated with RGM 191, in both var. Granny Smith and var. Royal Gala. The pathogen was reisolated in just $81 \%$ of the symptomatic var. Granny Smith inoculated with RGM 2161.
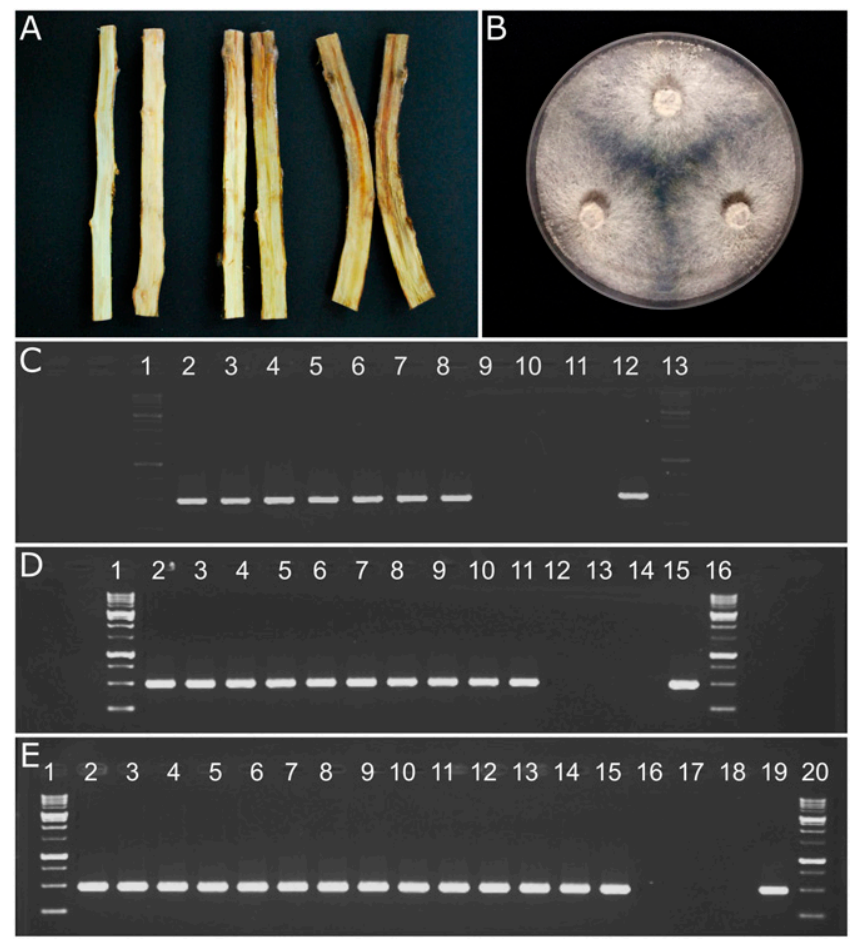

Fig. 3. Detection of Chondrostereum purpureum from apple wood using APN 1 primers. A, Control cutting inoculated with a sterile agar plug (left), a plug of RGM 206 (center), and a plug of RGM 191 (right). B, Mycelial development of RGM 2161 reisolated from inoculated cuttings, after 8 days incubation on APDA. C, PCR products of genomic DNA isolated from apple cuttings, inoculated with isolates RGM 146 (lane 2), RGM 191 (lane 3), RGM 206 (lane 4), RGM 2161 (lane 5), RGM 1323 (lane 6), RGM 2168 (lane 7), and RGM 2169 (lane 8), negative controls inoculated with sterile agar (lanes 9, 10, and 11) and positive control with standard isolate RGM 205 (lane 12). D, PCR products of DNA isolated from plants var. Royal Gala inoculated with: RGM 191 (lanes 2 to 6), RGM 2161 (lanes 7 to 11), and controls inoculated with sterile agar (lanes 12 to 14), and positive control (plant inoculated with standard isolate RGM 2161) (lane 15). E, Naturally infected nursery plants (lanes 2 to 15), healthy controls (lanes 16 to 18), and positive control (plant inoculated with the standard isolate RGM 205) (lane 19). Molecular weight standards are in the rightmost and leftmost lanes of the gels.

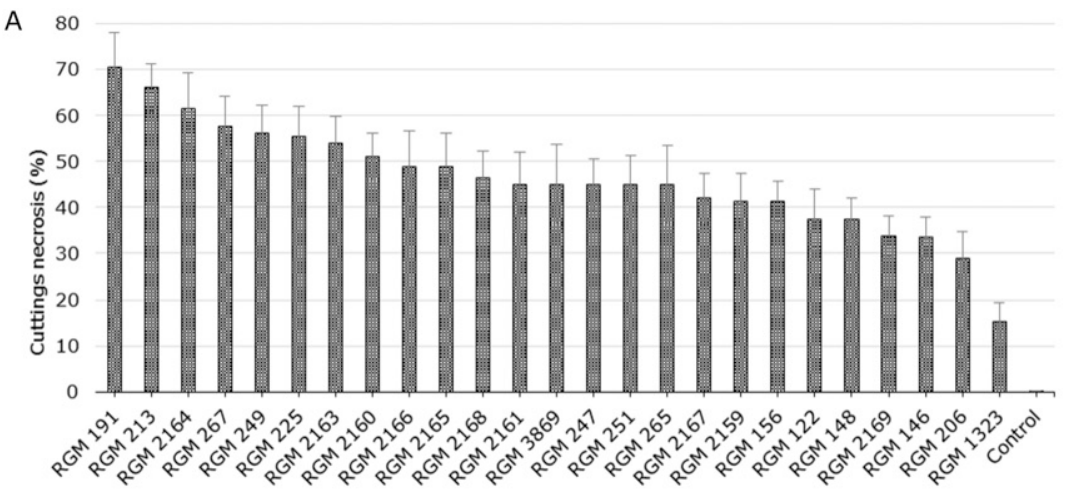

Chondrostereum purpureum isolates

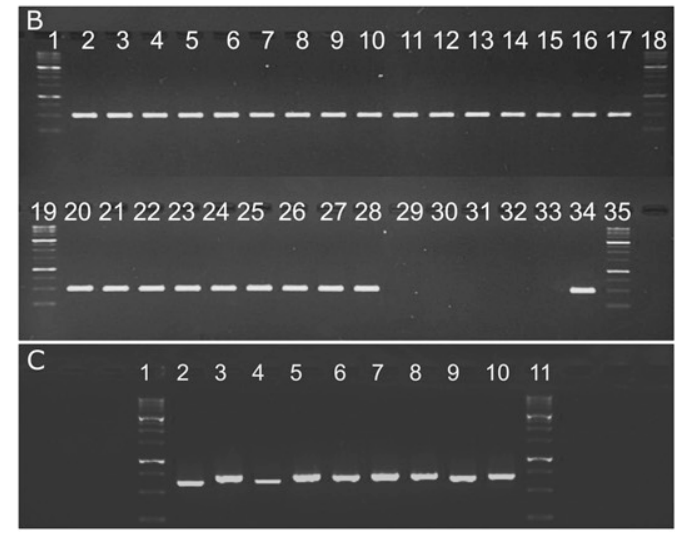

Fig. 2. A, Virulence of Chondrostereum purpureum isolates inoculated on apple var. Royal Gala cuttings. B, PCR products using APN 1 primers: C. purpureum isolates: RGM 191 to 1323 (lanes 2 to 17 and 20 to 28), Bjerkandera adusta (RGM 181), Schizophyllum commune (RGM 2171), Trametes versicolor (RGM 187), Stereum sp. (RGM 1319), and Ganoderma applanatum (RGM 1317) (lanes 29 to 33) and standard C. purpureum strain RGM 205 as a positive control (MK322287.1). C, PCR products using ITS primers: C. purpureum isolates RGM 191, 2163, 267, and 148 (lanes 2 to 5) and other basidiomycetes: RGM 181, 2171, 187, 1319, and 1317 (lanes 6 to 10). Molecular weight standards are in the rightmost and leftmost lanes of the gels. 
On the other hand, $100 \%$ of the plants collected from a commercial nursery var. Gala Brookfield showing foliar symptoms the previous season were positive for $C$. purpureum, using the APN 1 PCR technique. Instead, it was possible to reisolate the fungus in culture media from $92 \%$ of the samples. These results indicated that the PCR method is adequate to detect the pathogen in naturally infected nursery plants and inoculated plants, and the technique was more accurate and faster than the conventional microbiological isolation.

The protocol was also validated in naturally infected adult plants, since $100 \%$ of the tested trees were positive to $C$. purpureum using the APN 1 primers, discriminating from uninfected controls, which were negative. Thus, it was possible to detect the fungus in naturally infected plants showing different levels of foliar symptoms severity (Fig. 3E). The microbiological isolation, on the other hand, was possible for $80 \%$ of the samples.

\section{Discussion}

C. purpureum is a worldwide distributed wood inhabitant microorganism. Its pathological behavior is variable and fluctuates from being a tree stump saprophyte to a primary tree pathogen. Thus, although in the temperate zones of the northern hemisphere, $C$. purpureum is widely used as a mycoherbicide for forest woody weeds control (Gosselin et al. 1999), in Chile it is the causal agent of silverleaf, an important disease that affects fruit crops, diminishing tree longevity and reducing fruit yield and quality.

The plasticity of this fungus has allowed its adaptation to diverse hosts and geographic regions, as it occurs in different countries such as New Zealand, Canada, and The Netherlands, where C. purpureum is ubiquitous (De Jong et al. 1990; Gosselin et al. 1999; Spiers et al. 2000). In Chile it has been recorded from different host species and geographic areas (France et al. 2017; Grinbergs et al. 2019), as well as in this study, where the fungus was detected in nine different woody species causing silverleaf, and from a wide range of climate regions along the country. In addition, $C$. purpureum has been described as a weak pathogen in some countries (De La Bastide and Hintz 2007), while silverleaf has been classified as a major disease in Chile. Besides, this study demonstrated that all the tested isolates were pathogenic on apple, regardless of their host origin and suggesting cross infection among fruit species.

Early detection of the pathogen is essential to prevent the disease development and dissemination and is of major importance especially since foliar symptoms are visible two or three seasons after infection, according to our field surveys and to Spiers et al. (1998). Furthermore, to observe wood necrotic symptoms the plant has to be destroyed. In addition, wood staining is not always caused by C. purpureum and it may also be produced by defense mechanisms of the plant or other pathogens (Vartiamäki et al. 2009).

Isolation and incubation is the traditional diagnosis method for wood pathogens. Although this method is routinely used due to its simplicity, it is time-consuming and sometimes not accurate enough to detect the infection. Plus, the individual who performs this method has to have mycological skills. These are some of the reasons why more precise techniques have been adopted and used in diagnostics and early detection of pathogens. For instance, the molecular methods and serological techniques that are now used to study plant diseases are highly sensitive and specific (Capote et al. 2012; Ghasemkhani et al. 2016; Martinelli et al. 2015; Pouzoulet et al. 2017; Winkowska et al. 2016), as was the PCR technique developed in this study.

Becker et al. (1999) described a PCR method for the identification of $C$. purpureum in pure cultures by using APN 1 specific primers, in order to use C. purpureum as a biological agent to control woody weeds in conifer plantations, which were able to discriminate from other wood-rotting basidiomycetes, such as Trametes versicolor, Schizophyllum commune, Stereum hirsutum, Stereum sanguinolentum, Resinicium bicolor, and Phanerochaete chrysosporium. Based on Becker et al. (1999) research, a pure culture discrimination test was developed and PCR results produced an intensely discrete band of 500 bp from all $C$. purpureum isolates evaluated, whereas no products were amplified from the wood-rotting basidiomycetes
Trametes versicolor, Schizophyllum commune, and Stereum sp., previously evaluated by Becker et al. (1999), and after including the species Bjerkandera adusta and Ganoderma applanatum, which are also common apple wood inhabitants. This research has demonstrated that the protocol adapted from Becker et al. (1999), based in the use of APN 1 specific primers to detect $C$. purpureum from pure cultures, has become a rapid diagnostic tool to amplify the specific target sequence directly from apple woody tissues, without the need to isolate the fungus in culture media. At the same time, the standardized genomic DNA extraction procedure from apple woody tissues, based on the protocols described by Jasalavich et al. (2000) and Guglielmo et al. (2010), allowed the extraction of a high concentration of DNA free of inhibitors and its amplification.

Our test was able to produce the band in $100 \%$ of the inoculated cuttings, which also was verified by microbiological reisolation. Additionally, the assay did not amplify the apple DNA. APN 1 primers also detected the fungus in $100 \%$ of the inoculated plants; however, the microbiological isolation recovered the fungus in $90 \%$ of the positive samples. Similarly, Vartiamäki et al. (2009) inoculated Betula pendula with C. purpureum using mycelial plugs, and reproduced symptoms in $100 \%$ of the cases; meanwhile, they were able to isolate the fungus only from $79 \%$ of the samples.

For infections that occurred under natural conditions, this study showed that the traditional reisolation method detected $C$. purpureum in $80 \%$ of the infected trees and $92 \%$ of nursery plants. In contrast, the PCR-based method detected the disease in $100 \%$ of either category of the samples. These findings agree with Pouzoulet et al. (2017), who were able to detect Eutypa lata in 100\% of inoculated vine plants using qPCR, without differences between molecular detection and microbiological isolation. However, this difference was wider in naturally infected plants (63\% using qPCR than $2 \%$ using isolation). The reason for this big difference may rely on the quantity of mycelia in the tissues; thus, placing living mycelia directly in freshly wounded tissue increases the chance of infection compared with natural infection by airborne basidiospores (Vartiamäki et al. 2009).

We demonstrate that the PCR assay was sensitive, reliably and highly specific to $C$. purpureum, and discriminates the DNA from other fungal species occurring on apple. Moreover, it allowed the identification and differentiation of $C$. purpureum from living apple plants in less than $12 \mathrm{~h}$, avoiding the time-consuming process of isolation and identification that usually would take weeks. Thus, the assay proved to be a suitable tool for the detection of silverleaf in nurseries, allowing the early diagnosis in mother plants and thus helping in the prevention of disease dissemination, and in established orchards, helping growers to make decisions on proper timing and adequate management measures.

\section{Acknowledgments}

We thank Themis J. Michailides, Kearney Agricultural Center, University of California, for reviewing this manuscript.

\section{Literature Cited}

Alves, A., Phillips, A. J. L., Henriques, I., and Correia, A. 2007. Rapid differentiation of species of Botryosphaeriaceae by PCR fingerprinting. Res. Microbiol. 158:112-121.

Becker, E., Ball, L., and Hintz, W. 1999. PCR Based genetic markers for detection and infection frequency analysis of the biocontrol fungus Chondrostereum purpureum on Stika Alder and Trembling Aspen. Biol. Control 15:71-80.

Bus, V., Spiers, A., Brewster, D., and Hofstee, M. 1996. Preliminary screening of apple germplasm for resistance to silverleaf infection. N.Z. J. Crop Hortic. Sci. 24:1-6.

Capote, N., Pastrana, A. M., Aguado, A., and Sanchez-Torres, P. 2012 Molecular tools for detection of plant pathogenic fungi and fungicide resistance. Pages 151-202 in: Plant Pathology. C. J. R. Cumagun, ed. InTech, London, UK

Catal, M., Jordan, S. A., Butterworth, S. C., and Schilder, A. M. C. 2007 Detection of Eutypa lata and Eutypella vitis in grapevine by nested multiplex polymerase chain reaction. Phytopathology 97:737-747.

De Jong, M. D., Scheepens, P. C., and Zadoks, J. C. 1990. Risk analysis for biological control: A Dutch case study in biocontrol of Prunus serotina by the fungus Chondrostereum purpureum. Plant Dis. 74:189-194. 
De La Bastide, P. Y., and Hintz, W. E. 2007. Developing the production system for Chondrostereum purpureum. Pages 291-299 in: Biological Control: A Global Perspective. CABI International, Wallingford, UK.

France, A., Grinbergs, D., and Carrasco, J. 2017. First detection of Silverleaf (Chondrostereum purpureum) on rabbiteye blueberry (Vaccinium virgatum) and disease damages. Acta Hortic.: 277-282.

Ghasemkhani, M., Holefors, A., Marttila, S., Dalman, K., Zborowska, A., Rur, M., Rees-George, J., Nybom, H., Everett, K. R., Scheper, R. W. A., and GarkavaGustavsson, L. 2016. Real-time PCR for detection and quantification, and histological characterization of Neonectria ditissima in apple trees. Trees (Berl.) 30:1111-1125.

Gosselin, L., Jobidon, R., and Bernier, L. 1999. Genetic variability and structure of Canadian populations of Chondrostereum purpureum, a potential biophytocide. Mol. Ecol. 8:113-122.

Grinbergs, D., Chilian, J., Lisboa, K., and France, A. 2019. First report of Silverleaf disease caused by Chondrostereum purpureum on murta (Ugni molinae Turcz.) in Chile. Plant Dis. 103:2140.

Guglielmo, F., Gonthier, P., Garbelotto, M., and Nicolotti, G. 2010. Sampling optimization for DNA-based diagnosis of wood decay fungi in standing trees. Lett. Appl. Microbiol. 51:90-97.

Jasalavich, C. A., Ostrofsky, A., and Jellison, J. 2000. Detection and identification of decay fungi in spruce wood by restriction fragment length polymorphism analysis of amplified genes encoding rRNA. Appl. Environ. Microbiol. 66: 4725-4734.

Lecomte, P., and Bailey, D. J. 2011. Studies on the infestation by Eutypa lata of grapevine spring wounds. VITIS-Journal Grapevine Res. 50:35.

Luque, J., Elena, G., García-Figueres, F., Reyes, J., Barrios, G., and Legorburu, F. J. 2014. Natural infections of pruning wounds by fungal trunk pathogens in mature grapevines in Catalonia (Northeast Spain). Aust. J. Grape Wine Res. 20:134-143.

Martinelli, F., Scalenghe, R., Davino, S., Panno, S., Scuderi, G., Ruisi, P., Villa, P., Stroppiana, D., Boschetti, M., Goulart, L. R., Davis, C. E. and Dandekar, A. M. 2015. Advanced methods of plant disease detection. A review. Pages 1-25 in: Agronomy for Sustainable Development. Springer Verlag/EDP Sciences/ INRA, 2015, 35 (1).

Morales-Cruz, A., Allenbeck, G., Figueroa-Balderas, R., Ashworth, V. E., Lawrence, D. P., Travadon, R., Smith, R. J., Baumgartner, K., Rolshausen, P., and Cantu, D. 2017. Closed-reference metatranscriptomics enables in planta profiling of putative virulence activities in the grapevine trunk-disease complex. Mol. Plant Pathol. 19. https://doi.org/10.1111/mpp.12544

Ogawa, E., Zehr, G., Bird, D., Ritchie, K., Uriu, K., and Uyemoto, J. K. 2000. Compendium of Stone Fruit Diseases. American Phytopathological Society, St. Paul, MN, USA.

Pavlic, D., Slippers, B., Coutinho, T. A., and Wingfield, M. J. 2009. Multiple gene genealogies and phenotypic data reveal cryptic species of the Botryosphaeriaceae: A case of study on the Neofusicoccum parvum/N. ribis complex. Mol. Phylogenet. Evol. 51:259-268.

Pearce, R. B., Sumer, S., Doran, S. J., Carpenter, T. A., and Hali, L. D. 1994. Noninvasive imaging of fungal colonization and host response in the living sapwood of sycamore (Acer pseudoplatanus L.) using nuclear magnetic resonance. Physiol. Mol. Plant Pathol. 45:359-384.

Phillips, A. J. L., Lopes, J., Abdollahzadeh, J., Bobev, S., and Alves, A. 2012. Resolving the Diplodia complex on apple and other Rosaceae hosts. Persoonia. Mol. Phylogeny Evol. Fungi. 29:29-38.
Pouzoulet, J., Rolshausen, P. E., Schiavon, M., Bol, S., Travadon, R., Lawrence, D. P., Baumgartner, K., Ashworth, V. E., Comont, G., Corio-Costet, M. F., Pierron, R. J. G., Besson, X., and Jacques, A. 2017. A method to detect and quantify Eutypa lata and Diplodia seriata-Complex DNA in grapevine pruning wounds. Plant Dis. 101:1470-1480.

Rolshausen, P. E., Trouillas, F., and Gubler, W. D. 2004. Identification of Eutypa lata by PCR-RFLP. Plant Dis. 88:925-929.

Rolshausen, P. E., Úrbez-Torres, J. R., Rooney-Latham, S., Eskalen, A., Smith, R. J., and Gubler, W. D. 2010. Evaluation of pruning wound susceptibility and protection against fungi associated with grapevine trunk diseases. Am. J. Enol. Vitic. 61:113-119.

Setliff, E. C. 2002. The wound pathogen Chondrostereum purpureum, its history and incidence on trees in North America. Aust. J. Bot. 50:645-651.

Simpson, R. M., Van Hekezen, R., Van Lune, F., Brewster, D., and Spiers, A. G. 2001. Extracellular enzymes of Chondrostereum purpureum, causal fungus of silverleaf disease. Pages 202-208 in: New Zealand Plant Protection Vol. 54 Proceedings of a conference, Quality Hotel, Palmerston North, New-Zealand.

Sosnowski, M. R., Creaser, M. L., Wicks, T. J., Lardner, R., and Scott, E. S. 2008 Protection of grapevine pruning wounds from infection by Eutypa lata. Aust. J. Grape Wine Res. 14:134-142.

Spagnolo, A., Marchi, G., Peduto, F., Phillips, A. J., and Surico, G. 2011 Detection of Botryosphaeriaceae species within grapevine woody tissues by nested PCR, with particular emphasis on the Neofusicoccum parvum/N. ribis complex. Eur. J. Plant Pathol. 129:485-500.

Spiers, A., Brewster, D., Bus, V., and Hopcroft, H. 1998. Seasonal variation in susceptibility of xylem tissue of Malus, Pyrus, Prunus, and Salix species to Chondrostereum purpureum in New Zealand. Mycol. Res. 102:881-890.

Spiers, A., Brewster, D., Slade, A., and Gardiner, S. 2000. Characterization of New Zealand isolates of Chondrostereum purpureum with regard to morphology, growth, pathogenicity and RAPD bandings patterns. Mycol. Res. 104:395-402

Spiers, A., Edwards, W., and Hopcroft, D. 1987. Effects of Silverleaf infection on ultrastructure of foliage of Prunus, Rosa, and Populus. N.Z. J. Bot. 25:411-423.

Spiers, A. G., and Brewster, D. 1997. Evaluation of chemical and biological treatments for control of Chondrostereum purpureum infection of pruning wounds in willows, apples, and peaches. N.Z. J. Crop Hortic. Sci. 25:19-31.

Spiers, A. G., and Hopcroft, D. H. 1988. Factors affecting Chondrostereum purpureum infection of Salix. Eur. J. Forest Pathol. 18:257-278.

Úrbez-Torres, J. R., Adams, P., Kamas, J., and Gubler, W. D. 2009. Identification, incidence, and pathogenicity of fungal species associated with grapevine dieback in Texas. Am. J. Enol. Vitic. 60:4.

Úrbez-Torres, J. R., Peduto, F., Smith, R. J., and Gubler, W. D. 2013. Phomopsis dieback: A grapevine trunk disease caused by Phomopsis viticola in California Plant Dis. 97:1571-1579.

Vartiamäki, H., Hantula, J., and Uotila, A. 2009. Susceptibility of silver birch pruning wounds to infection by white-rot fungus (Chondrostereum purpureum), a potential bioherbicide. Silva Fenn. 43:537-547.

White, T. J., Bruns, T., Lee, S. B., and Taylor, J. 1990. Amplification and direct sequencing of fungal ribosomal RNA genes for phylogenetics. Pages 315-322 in: PCR protocols: A Guide to Methods and Applications. M. A. Innis, D. H. Gelfand, J. J. Sninsky, and T. J. White, eds. Academic Press, San Diego, CA.

Winkowska, L., Grimová, L., and Rysanek, P. 2016. Quantitative detection of four fruit viruses in apple trees throughout the year. Phytopathol. Mediterr. 55: 207-224. 